Research Article

\title{
Postoperative antibiotic therapy patterns in benign prostatic hyperplasia (BPH) patients
}

\author{
Aghnia Fuadatul Inayah ${ }^{[1]}$, Rizki Lisya Nugraha[1], Didik Hasmono ${ }^{[2]^{*}}$ \\ 1 Department of Pharmacy, Faculty of Health Sciences, University of Muhammadiyah Malang, Malang, East Java, \\ Indonesia \\ 2 Department of Pharmacy, Faculty of Pharmacy, Airlangga University, Surabaya, East Java, Indonesia \\ Corresponding Author's Email: gwae23@yahoo.com
}

\begin{tabular}{|c|c|}
\hline ARTICLE INFO & ABSTRACT \\
\hline $\begin{array}{l}\text { Article History } \\
\text { Received October 5, } 2020 \\
\text { Revised October 19, } 2020 \\
\text { Accepted October 26, } 2020 \\
\text { Published February 1, } 2021 \\
\text { Keywords } \\
\text { Benign Prostatic Hyperplasia } \\
\text { Antibiotic prophylactic } \\
\text { Antibiotic empiric } \\
\text { Postoperative } \\
\text { Doi } \\
\text { 10.22219/farmasains.v5i2.13942 }\end{array}$ & $\begin{array}{l}\text { Benign Prostatic Hyperplasia (BPH) is an enlarged prostate disease benign } \\
\text { or a condition when the cells are present the prostate gland has an } \\
\text { increased proliferation rate. There are several treatment options, including } \\
\text { conservative (watchful waiting), medical, and surgery. Antibiotics in BPH } \\
\text { cases can be prophylactic antibiotics or empiric antibiotics. This study was } \\
\text { an observational study. The samples were BPH patients who received } \\
\text { antibiotics for period January - November 2019. The pattern of } \\
\text { prophylactic antibiotic use shows that most of the patients received } \\
\text { ceftriaxone therapy. Operation on BPH patients is TURP which is an } \\
\text { operation classified into surgery with a clean-contaminated category so } \\
\text { that prophylactic antibiotics are required. There are two patterns of use } \\
\text { for empiric antibiotics in BPH patients: single (88\%) and combination } \\
\text { (12\%). The pattern of single or combined use is given to patients } \\
\text { depending on the complications of the disease and the patient's clinical } \\
\text { condition. BPH cases occur in men mostly occurs at the age of } 60-74 \text { years. } \\
\text { Prophylactic antibiotic therapy in BPH patients, namely ceftriaxone } 1 \text { gr IV } \\
\text { once daily was } 48 \text { patients ( } 90.6 \% \text { ), a broad spectrum. Meanwhile, the } \\
\text { most use of empirical antibiotics with a single pattern is Ceftriaxone } 1 \text { gr IV } \\
\text { twice daily ( } 35.6 \% \text { ). }\end{array}$ \\
\hline
\end{tabular}

\section{INTRODUCTION}

The prostate is a heart-shaped, solid and round male genital organ positioned between the bladder neck and the urogenital diaphragm. Benign prostatic hyperplasia (BPH) is an enlarged prostate disease benign or a condition when the cells are present the prostate gland has an increased proliferation rate (Montorsi \& Mercadante, 2013). BPH is characterized by changes in stromal cells and a persistent epithelium proliferation around the urethra, causing Lower Urinary Tract Symptoms (LUTS) (Leibbrand et al., 2019). Generally, a man who experiences LUTS begins to appear when a person has passed 50 years old (Montorsi \& Mercadante, 2013). Data from Crimpen and the Baltimore Longitudinal Study of Aging (BLSA) show that prostate volume increases by $2.0 \%-2.5 \%$ per year in advancing age. In general, BPH continues to increase linearly up to $70-80 \%$ at age > 80 years old (Madersbacher, Sampson \& Culig, 2019).

Management of BPH patient therapy is to improve the patient's quality of life. Therapy given to patients depends on the degree of a complaint, the patient's condition, and the availability of local facilities. Several treatment options include conservative (watchful waiting), medical, and surgery (Ikatan Ahli Urologi Indonesia [IAUI]., 2017). Surgery is the best long-term symptom resolution and is indicated in patients with severe 
symptoms. Transurethral Resection of the Prostate (TURP) is the most commonly performed procedure because it can improve $70 \%$ to $96 \%$ of symptoms with a mortality rate of $0 \%$ to $0.25 \%$ (Smith, Preminger, Badlani \& Kavoussi, 2019). Surgical therapy of BPH can lead to infection. Based on data held by WHO, the incidence of surgical wound infection is not known globally. The incidence of surgical wound infection in Southeast Asia is $7.8 \%$ (Lim, 2017). TURP surgery is a clean, contaminated operation. The risk of infection in clean-contaminated surgery is $4-10 \%$. Therefore, patients who are at risk of infection need antibiotic therapy.

Antibiotics in cases of BPH can be prophylactic antibiotics or empiric antibiotics. The use of prophylactic antibiotics, namely prevention and reduction of the incidence of surgical wound infections, lower postoperative morbidity and mortality, less susceptible to resistance, and minimizing health care costs. Meanwhile, empiric antibiotics are given with the aim of inhibiting the growth of the patient's infection which is visible from clinical signs but has not yet carried out a culture examination (Peraturan Menteri Kesehatan Republik Indonesia, 2011). The use of antibiotics is very important for BPH patients, especially those who receive surgery. Therefore, analysis of antibiotic use in BPH patients is important as monitoring of antibiotic use and as a process for evaluating drug use.

\section{MATERIALS AND METHODS}

The research method used is an observational study because the researcher did not provide direct treatment to the sample studied. The research design was carried out descriptively with retrospective data collection methods, namely by processing the Patients Medical Record (PMR). The samples were BPH patients who received antibiotics at the Kediri District Hospital for the period of January - November 2019. Inclusion data included all BPH patients with or without comorbidities who received tranexamic acid therapy and were equipped with complete patient MR data.

\section{RESULTS AND DISCUSSIONS}

\section{Demographic Patients}

From fifty nine PMR, demographic data were obtained which included data on age and patient insurance status. In the patient demographic data based on age, the dominant data obtained, namely in the age range 60 to 74 years old, as many as 31 patients ( $58.5 \%$ (Table 1 ). BPH is a disease that is often found in elderly men. The prostate will gradually increase in size and lead to BPH at more than 60 years old. The percentage of the incidence of BPH is more than $50 \%$ at the age of more than 60 years old and at the age of 85 years old as much as $90 \%$ of men will experience BPH (Harun, 2019).

Meanwhile, the classification of the age range for the elderly according to the WHO includes middle age range 45 to 59 years old, elderly age range of 60 to 74 years old, elderly people age range of 75 up to 90 years old, and very old age range above 90 years old. In a study conducted by Mulyadi \& Sugiarto (2020), on the prevalence of BPH in Cibinong Hospital for the period of January 2017 - August 2019, there were 287 cases (93.46\%). With the most frequent occurrence in 2018, there were 117 cases (40.76\%). The distribution of the most age group cases of BPH was in the age range $65-74$ years old with 125 cases (43.55\%), and the least was found in the age range 85 - 94 years old with eight cases $(2.79 \%)$.

Further demographic data on patient care status, the most data obtained were patients with BPJS status as many as thirty nine patients (73.6\%) (Table 2). Badan Penyelenggara Jaminan Sosial or The Social Insurance

Table 1. WHO age classification of BPH patients

\begin{tabular}{lll}
\hline Age Classification & Number of Patients & Percentage (\%) \\
\hline Middle age & 8 & 15.1 \\
Elderly & 31 & 58.5 \\
Old & 14 & 26.4 \\
\hline Amount & $\mathbf{5 3}$ & $\mathbf{1 0 0}$ \\
\hline
\end{tabular}

Table 2. BPH Patient Guarantee Status

\begin{tabular}{lll}
\hline Patients Care Status & Number of Patients & Percentage (\%) \\
\hline BPJS & 39 & 73.6 \\
General & 14 & 26.4 \\
\hline Amount & $\mathbf{5 3}$ & $\mathbf{1 0 0}$ \\
\hline
\end{tabular}

Cite: Inayah, A. F., Nugraha, R. L., \& Hasmono, D. (2020). Postoperative antibiotic therapy patterns in benign prostatic hyperplasia (BPH) patients. Farmasains : Jurnal Farmasi dan Ilmu Kesehatan, 5(2), 57-62. doi:10.22219/farmasains.v5i2.13942 
Table 3. Distribution of the use of antibiotic prophylaxis in BPH patients

\begin{tabular}{lll}
\hline Antibiotic Dosing Regimen & Number of Patients & Percentage (\%) \\
\hline Ceftriaxone 1 gr IV once daily & 48 & 90.6 \\
Gentamicin 150 mg IV once daily & 5 & 9.4 \\
\hline Amount & $\mathbf{5 3}$ & $\mathbf{1 0 0}$ \\
\hline
\end{tabular}

Table 4. Empirical antibiotic use patterns in BPH patients

\begin{tabular}{lll}
\hline Antibiotic Pattern & Number of Patients & Percentage (\%) \\
\hline Single & 59 & 88 \\
Combination & 8 & 12 \\
\hline Amount & $\mathbf{6 7}$ & $\mathbf{1 0 0}$ \\
\hline
\end{tabular}

Administration Organization (BPJS) is a program for a health insurance institution established by following Indonesia's insurance costs. The government strives to achieve equal distribution of public health welfare by providing a Health Insurance program (Khasanah, Santoso \& Fatiha., 2020).

\section{Prophylactic Antibiotic Therapy in BPH Patients}

The pattern of prophylactic antibiotic use shows that most of the patients received ceftriaxone therapy with $1 \mathrm{gr}$ IV once daily dose regimen of forty eight patients (90.6\%) (Table 3).Operation on BPH patients is TURP which is an operation classified into surgery with a clean-contaminated category so that prophylactic antibiotics are required (Li et al., 2017). Infection is a risk for any intervention. In surgery, more pathogenic bacteria are found in $90 \%$ of surgical wounds during the closure. These bacteria are only a few but can reproduce. In the case of surgery, the risk increases. The goal of prophylactic antibiotics is to prevent bacterial growth in order to reduce the risk of infection at the intervention site (Martin et al., 2019).

American Urological Association (AUA) recommends second and third-generation cephalosporin therapy, such as ceftriaxone as prophylaxis for the TURP procedure. Ceftriaxone is a third-generation cephalosporin antibiotic that has bactericidal activity. Also, it can work on a broad spectrum of both gram-positive or negative bacteria but has a gram-negative activity greater than the first and second-generation drugs. Ceftriaxone inhibit or damage the synthesis of bacterial cell walls by blocking the third stage of the transpeptidase reaction which is a series of bacterial cell wall formation, so the cell membrane is less osmotically stable, which causes the incomplete cell wall to undergo lysis and the bacteria die (Katzung \& Trevor, 2015; Wells, DiPiro, Schwinghammer \& DiPiro, 2015; Chung \& Lee, 2019).

The results of the study (Table 3) also showed the use of gentamicin as a prophylactic antibiotic. One study found that in all, a total of thirty antibiotic regimens were used. The single most commonly prescribed single antibiotic regimens were ciprofloxacin (32\%), cefazolin (25\%), and gentamicin (3\%). Patients undergoing TURP with a foley catheter in place can increase the risk of infection. The use of gentamicin in these patients shows a reasonably stable condition and reduces infection risk (Lawson, Rudzinski, Vicas \& Carlson, 2013).

Postoperative bacteriuria and surgical site infection incidence was higher in patients who received antibiotics for a short time. Postoperative infectious complications depend on old age, short duration of antibiotic administration, and prolonged foley catheterization (Shin, Chung, Hwang, Jung, \& Kwo, 2017). In addition, the use of prophylactic antibiotics in surgery reduces urinary tract complications. If the patient has a subsequent infection, prophylactic antibiotics will reduce antibiotic therapy's working period for urinary tract infections. In terms of costs, the use of antibiotics also saves hospital care costs (Fisher et al., 2018).

\section{Empirical Antibiotic Therapy in BPH Patients}

There are two patterns of use for empiric antibiotics in BPH patients: single (88\%) and combination (12\%). The pattern of single or combined use is given to patients depending on the disease's complications and the patient's clinical condition. The most empiric antibiotic use was in a single-use pattern of fifty nine patients (Table 4).

Empirical antibiotic use patterns Single patients with BPH received the most ceftriaxone $1 \mathrm{gr}$ IV twice daily (35.6\%) (Table 5). Cephalosporin antibiotics dominate empirical antibiotic therapy. Other antibiotics such as amoxicillin $500 \mathrm{mg}$ PO three times daily are a penicillin derivative group with broad-spectrum activity so that they are potent enough to overcome gram-negative and gram-positive bacterial infections. 
Table 5. Distribution of single pattern empirical antibiotic usage

\begin{tabular}{lll}
\hline Antibiotic Pattern & Number of patients * & Percentage (\%) \\
\hline Ceftriaxone 1 gr IV twice daily & 21 & 35.6 \\
Cefixime 200 mg PO twice daily & 3 & 5.1 \\
Cefadroxil 500 mg PO twice daily & 2 & 3,4 \\
Amoxicillin 500 mg PO three times daily & 17 & 28.8 \\
Ciprofloxacin 200 mg IV twice daily & 5 & 8.5 \\
Ciprofloxacin 500 mg PO three times daily & 8 & 13.5 \\
Levofloxacin 500 mg PO once daily & 2 & 3,4 \\
Gentamicin Ointment 0.1\% & 1 & 1.7 \\
\hline Amount & $\mathbf{5 9}$ & $\mathbf{1 0 0}$ \\
\hline
\end{tabular}

Table 6. Distribution of combination pattern empirical antibiotic use

\begin{tabular}{lll}
\hline Antibiotic Pattern & Number of patients & Percentage (\%) \\
\hline Ceftriaxone 2x1 g IV + Amoxicillin 3x500 mg PO & 7 & 87.5 \\
Amoxicillin 3x500 mg PO + Ciprofloxacin 3x500 mg PO & 1 & 12.5 \\
\hline Amount & $\mathbf{8}$ & $\mathbf{1 0 0}$ \\
\hline
\end{tabular}

Infections that occur after transurethral manipulation are more likely to be caused by the Pseudomonas $s p .$, which have a higher level of resistance to cephalosporins and carbapenems. A transrectal prostate biopsy can lead to postoperative infections. Perioperative antibiotics have reduced postoperative prostatitis rates to between $0.67 \%$ to $2.10 \%$ of cases (Coker \& Dierfeldt, 2016). Thus, the use of empiric antibiotics is important if postoperative signs of infection appear and reduce the incidence of postoperative infection (Atalay, Canat, Alkan, Çakir \& Altunrende, 2017). However, doing blood culture tests is very important to deal with infections that could be more severe (Coker \& Dierfeldt, 2016).

In addition, some patients received ciprofloxacin IV therapy as well as PO and IV levofloxacin. These antibiotics can be used to treat urinary tract infections. Escherichia coli generally causes bacteria that cause urinary tract infections. Other common causative microorganisms include Enterobacteriaceae such as Klebsiella pneumonia and gram-positive bacteria such as Enterococci $s p$. The recommended antibiotic is the fluoroquinolone group (Kang et al., 2018). Ciprofloxacin is quite effective as an empiric antibiotic to treat urinary tract infections and is potent enough to treat other infections. In addition, the use of ciprofloxacin has a fairly low level of resistance (Gutiérrez-Castrellón, Díaz-García, de Colsa-Ranero, Cuevas-Alpuche \& Jiménez-Escobar, 2015). Meanwhile, the use of levofloxacin is not much different from ciprofloxacin to treat urinary tract infections (Lee et al., 2014).

The pattern of using the most combination empiric antibiotics used was a combination of ceftriaxone $1 \mathrm{~g}$ IV twice daily and amoxicillin $500 \mathrm{mg}$ three times in seven patients (Table 6). The use of a combination is likely to be used to prevent Urinary Tract Infections (UTI), so combination therapy is chosen (Mangarengi \& Octavia, 2019). Not only that, because the patient's condition was getting better, the drug administration was replaced by PO. The administration of more than one antibiotic is usually used to treat Multidrug-resistant Bacteria (MDR), but scientific evidence does not support the use of combination therapy in most cases. Examples of cases that can use combination therapy include sepsis due to Carbapenem-resistant Enterobacteriaceae (CRE), pneumococcal bacteremia pneumonia, and multiple organ failure patients. Thus, this treatment combination cannot be given without good reasons (Ahmed, Azim, Gurjar \& Baronia, 2014).

\section{CONCLUSIONS}

BPH cases occur in men because of the age factor that mostly occurs at age range $60-74$ years old. The use of prophylactic antibiotic therapy in BPH patients, namely ceftriaxone with a $1 \mathrm{gr}$ IV once daily was forty eight patients (90.6\%) which is a broad spectrum. Meanwhile, the most use of empirical antibiotics with a single pattern is ceftriaxone $1 \mathrm{gr}$ IV once daily (35.6\%). Not only single, but there is also a combination pattern dominated by the combination of ceftriaxone $1 \mathrm{gr}$ IV twice daily and amoxicillin $500 \mathrm{mg}$ three times daily (87.5\%) which aims to treat urinary tract infections. 


\section{REFERENCES}

Ahmed, A., Azim, A., Gurjar, M., \& Baronia, A. K. (2014). Current concepts in combination antibiotic therapy for critically ill patients. Indian Journal of Critical Care Medicine, 18(5), 310-314. doi:10.4103/09725229.132495

Atalay, H. A., Canat, L., Alkan, I., Çakir, S. S., \& Altunrende, F. (2017). Prostate-specific antigen reduction after empiric antibiotic treatment does not rule out biopsy in patients with lower urinary tract symptoms: prospective, controlled, single-center study. Prostate International, 5(2), 59-64. doi:10.1016/ j.prnil.2017.03.003

Chung, D. Y., \& Lee, J. Y. (2019). Recommendations for Antibacterial Prophylaxis in Endourological Procedures. Urogenital Tract Infection, 14(1), 1-8. doi:10.14777/uti.2019.14.1.1

Coker, T. J., \& Dierfeldt, D. M. (2016). Acute bacterial prostatitis: Diagnosis and management. American Family Physician, 93(2), 114-120.

Wells, B. G., DiPiro, J. T., Schwinghammer, T. L., \& DiPiro, C. V. (2015). Pharmacoterapy Handbook, 9th ed. New York, NY: McGraw-Hill Education.

Fisher, H., Oluboyede, Y., Chadwick, T., Abdel-Fattah, M., Brennand, C., Fader, M., ... Pickard, R. (2018). Continuous low-dose antibiotic prophylaxis for adults with repeated urinary tract infections (AnTIC): a randomised, open-label trial. The Lancet Infectious Diseases, 18(9), 957-968. doi:10.1016/S1473-3099(18) 30279-2

Gutiérrez-Castrellón, P., Díaz-García, L., de Colsa-Ranero, A., Cuevas-Alpuche, J., \& Jiménez-Escobar, I. (2015). Efficacy and safety of ciprofloxacin in the treatment of urinary tract infections (UTI) in adults: A systematic review with meta-analysis. Gaceta Medica de Mexico, 151(2), 225-244.

Harun, H. (2019). Aspek Laboratorium Benign Prostatic Hyperplasia. Jurnal IImiah Kedokteran, 6(3), 1-27.

Ikatan Ahli Urologi Indonesia. (2017). Panduan Penatalaksanaan Klinis Pembesaran Prostat Jinak (Benign Prostatic Hyperplasia/ BPH). Jakarta, Indonesia: Authors

Kang, C. I., Kim, J., Park, D. W., Kim, B. N., Ha, U. S., Lee, S. J., ... \& Wie, S. H. (2018). Clinical practice guidelines for the antibiotic treatment of community-acquired urinary tract infections. Infection \& chemotherapy, 50 (1), 67-100doi:10.3947/ic.2018.50.1.67

Katzung, B. G., \& Trevor, A. J. (2015). Basic and Clinical Pharmacology, 13th Ed. New York, NY: McGraw-Hill Education.

Khasanah, U., Santoso, A., \& Fatiha, C. N. (2020). Evaluation of BPJS and Non BPJS Outpatient Satisfaction for the Quality of Service in the Pharmacy Installation of Tugurejo Regional Hospital of Central Java Province. Sultan Agung Fundamental Research Journal, 1(1), 83-92.

Lawson, K. A., Rudzinski, J. K., Vicas, I., \& Carlson, K. V. (2013). Assessment of Antibiotic Prophylaxis Prescribing Patterns for TURP: A Need for Canadian Guidelines?. Canadian Urological Association Journal, 7(7-8), E530. doi:10.5489/cuaj.205

Lee, M. T. G., Lee, S. H., Chang, S. S., Lee, S. H., Lee, M., Fang, C. C., ... \& Lee, C. C. (2014). Comparative effectiveness of different oral antibiotics regimens for treatment of urinary tract infection in outpatients: An analysis of national representative claims database. Medicine (United States), 93(28), e304. doi:10.1097/MD.0000000000000304

Leibbrand, M., Siefer, S., Schön, C., Perrinjaquet-Moccetti, T., Kompek, A., Csernich, A., ... \& Kreuter, M. H. (2019). Effects of an Oil-Free Hydroethanolic Pumpkin Seed Extract on Symptom Frequency and Severity in Men with Benign Prostatic Hyperplasia: A Pilot Study in Humans. Journal of Medicinal Food, 22(6), 551559. doi:10.1089/jmf.2018.0106

Li, Y. H., Li, G. Q., Guo, S. M., Che, Y. N., Wang, X., \& Cheng, F. T. (2017). Urinary tract infection in patients undergoing TURP. European Review for Medical and Pharmacological Sciences, 21, 4487-4492. 
Lim, K. B. (2017). Epidemiology of clinical benign prostatic hyperplasia. Asian Journal of Urology, 4(3), 148-151. doi:10.1016/j.ajur.2017.06.004

Madersbacher, S., Sampson, N., \& Culig, Z. (2019). Pathophysiology of Benign Prostatic Hyperplasia and Benign Prostatic Enlargement: A Mini-Review. Gerontology, 65(5), 458-464. doi:10.1159/000496289

Mangarengi, Y., \& Octavia, S. D. R. (2019). Infeksi Saluran Kemih (ISK) Komplikata Di Rumah Sakit Ibnu Sina Makassar. UMI Medical Journal, 4(1), 130-140. doi:10.33096/umj.v4i1.58

Martin, C., Auboyer, C., Boisson, M., Dupont, H., Gauzit, R., Kitzis, M., ... \& Pourriat, J. L. (2019). Antibioprophylaxis in surgery and interventional medicine (adult patients). Update 2017. Anaesthesia Critical Care and Pain Medicine, 38(5), 549-562. doi:10.1016/j.accpm.2019.02.017

Montorsi, F., \& Mercadante, D. (2013). Diagnosis of BPH and treatment of LUTS among GPs: A European survey. International Journal of Clinical Practice, 67(2), 114-119. doi:10.1111/j.1742-1241.2012.03012.x

Mulyadi, H. T. S., \& Sugiarto, S. (2020). Prevalensi Hiperplasia Prostat dan Adenokarsinoma Prostat secara Histopatologi di Laboratorium Patologi Anatomi Rumah Sakit Umum Daerah Cibinong. Muhammadiyah Journal of Geriatric, 1(1), 12. doi:10.24853/mujg.1.1.12-17

Peraturan Menteri Kesehatan Republik Indonesia. (2011). Peraturan Menteri Kesehatan Republik Indonesia Nomor 2406/Menkes/Per/XII/2011 Tentang Pedoman Umum Penggunaan Antibiotik. Jakarta, Indonesia: Authors.

Shin, B., Chung, H. S., Hwang, E. C., Jung, S. II, \& Kwon, D. D. (2017). Antibiotic prophylaxis in radical prostatectomy: Comparison of 2-day and more than 2-day prophylaxis. Journal of Korean Medical Science, 32(6), 1009-1015. doi:10.3346/jkms.2017.32.6.1009

Smith, A. D., Preminger, G., Badlani, G. H., \& Kavoussi, L. R. (2019). Smith's Textbook of Endourology. Hoboken, NJ: John Wiley \& Sons Ltd.

Cite: Inayah, A. F., Nugraha, R. L., \& Hasmono, D. (2020). Postoperative antibiotic therapy patterns in benign prostatic hyperplasia (BPH) patients. Farmasains : Jurnal Farmasi dan IImu Kesehatan, 5(2), 57-62. doi:10.22219/farmasains.v5i2.13942 